\title{
Professor Brock discovered Thermus aquaticus most precious enzyme source to run the PCR is a great affair: on his demise subject in precise
}

\author{
Tapas Goswami ${ }^{1}$
}

${ }^{1}$ Emeritus Scientist, Immunology Section, Indian Veterinary Research Institute, Izatnagar-243 122, Uttar Pradesh, India

\section{Human prosperity through scientific curiosity}

Scientific knowledge has improved the quality of our life at many different levels. Microbiologist Thomas Brock defending against the common believes that life is unsustainable at high temperature ultimately proved it wrong by discovering a microbe thriving in hot spring near to boiling temperature. To solve any problem basic research may not bring magical cure but it is sure, it can inspire others for translational research to bring prosperity in human society. In present situation, veterinary profession is not restricted in treatment and animal husbandry rather crossed the boundary to involve them in fundamental research in technology driven era.

\section{Research result opened hidden vault}

In the year 1966, Thomas Brock, a microbiologist, along with one of his graduate

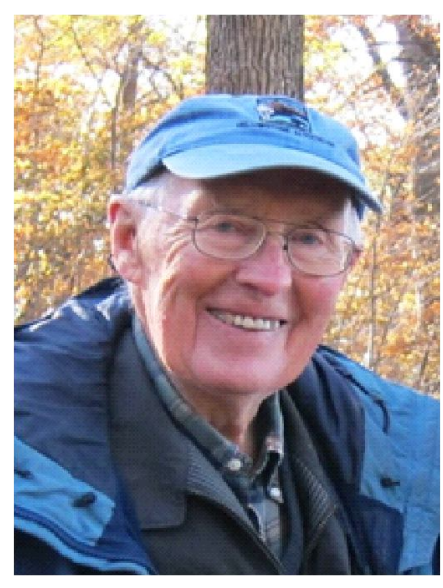

Thomas Dale Brock 1926-2021 student Hudson Freeze discovered a bacterium in the thermal vents of Y e 11 ow s to n e National Park (situated northwest region of US). That microbe can survive extreme temperature near to $80^{\circ} \mathrm{C}$ (Brock and Freeze, 1969). Normally such high temperature was known to be unfavourable temperature for bacterial survival, but they proved it was incorrect. Even though the temperature of water was near to $79^{\circ} \mathrm{C}$, the isolated microbes were not dead, rather were in happy state of life, as microscopic study revealed. Brock identified these thermophilic bacteria and named it Thermus aquaticus. Graduate student Freeze studied further and reported that enzymes from Thermus aquaticus were able to tolerate higher than maximum growth temperature retaining their functional activity at boiling temperature. Within scientific knowledge, such an elevated temperature destroys the enzymatic activity responsible for protein synthesis mechanism in all other disease-causing bacteria of plants and animals. While discovery of Brock came to public as early as 1969, both Brock and Freeze received Golden Goose Award in the year 2013. The Golden Goose Award is given to scientists and engineers who have completed research projects supported by federal funding agencies that appeared to be insignificant at first instance but later its impact on science and society has been felt to be historic. At present Hudson Freeze has changed his research area from microbiology to glycobiology in human genetics program. Currently he is the Director of Sanford Children's Health Research, Orlando Florida, US.

\section{Small move of great improve}

Biochemist Kary Mullis, Nobel Prize recipient in 1993, used thermostable enzyme Taq having polymerase activity to demonstrate polymerase chain reaction technique in laboratories. Born in 1926, Brock worked 
extensively at Wisconsin University-Madison, US, till his retirement. Unfortunately, Kary Mullis name has been spooled with Thermus aquaticus whereas Brock's name remain cooled, reason unknown. PCR technique has revolutionized medicine, forensic science and biotechnology. Enzyme Taq polymerase has been purified and patented in December 1989 by Gelfend. Subsequently, Hoffman-LaRoche has acquired the patent rights for it (Gelfand et al., 1989).

\section{Gift of nature scientific treasure}

As Brock narrated in one of his publication, isolation of bacteria surviving at high temperature from hot spring Yellowstone National Park was "experiments in nature" and according to him finding of bacteria at high temperature was an "unexpected discovery". The heat stable enzyme Taq polymerase derived from this bacterium is so esteemed that it was recognised by the White House in 1991 (Brock, 1997). Brock was too generous and had humanitarian mind. Due to his high morality, he never asked any royalty for his discovery and earned nothing out of this microbe whereas the Swiss pharma company Hoffmann-LaRoche is earning million dollars from the microbe derived Taq polymerase enzyme and the PCR technique driven by this enzyme. There should not be any hesitation to accept that it is PCR which has placed Thermus aquaticus in the celebrity map in scientific world. Ultimately after retirement, Brock created the pleasant valley conservancy state natural area on 140 acres of land in Wisconsin. Working extensively on Yellowstone microbe, he characterized this microbe for final submission as Thermus aquaticus strain YT-1 to the American Type Culture Collection, popularly known as ATCC, from where we are receiving it frequently without knowing who has donated this treasure silently. Thomas Dale Brock passed away at home on $4^{\text {th }}$ April 2021 at the age of 94. At this time of grief let us discuss in brief about his contribution to glorify his reputation.

\section{Struggling from beginning}

From beginning he was interested in chemistry but after completion of graduation he joined electronics program in US Navy for about one and half years, eventually, joined Ohio State University in botany and received his graduation in the year 1949. As large plants were not of his choice of interest to study, he switched over to mycology and acquired Ph.D in 1952 working on fungi. With all these he kept alive his fascination towards plant ecology and chose to pursue microbial ecology in his professional carrier (Brock, 1995).

\section{Difficulty to be faculty}

To occupy a faculty position was difficult and postdoctoral position was too less in number at his time, so no choice was left over other than to join as research associate position for a temporary period to work on soil fungi at Ohio Agricultural Experiment Station (Wooster, Ohio). Luck by chance due to opening a position at the Upjohn Company (Michigan US) he could grab that position having expertise in soil mycology.

\section{Switching for teaching}

Due to repetitious routine work, he preferred to quit Upjohn and somehow managed to get entry as Assistant Professor in the Biology Department of Western Reserve University in his home town Cleveland. In spite of relatively low salary in academic position, initially he was contented to develop his own research programme and relished classroom teaching. Through class room teaching, he improved a lot to be real microbiologist and received two research grants on mode of action of antibiotics and yeast mating project, funded by Federal Funding Agencies. Within the end of year of post-doctoral position, he got one more chance to be a faculty member as Assistant Professor in Bacteriology at Indiana University, by which he got an opportunity to shift his research from botany to complete Microbiology including Medical Microbiology.

\section{Mentor and student never claimed patent}

It is worthy to mention here that the great discovery of Thermus aquaticus by Brock and his associates ultimately enabled the 
development of PCR. But neither mentor Brock nor the student(s) asked any share from the PCR business affair. Recognising the talent of Thomas Brock, the University of WisconsinMadison offered him a chair of professorship EB Fred Professor of Natural Sciences in 1971. In one of his publications he has stated that the most productive period of his carrier was the

\section{REFERENCES}

Brock TD and Freeze H, 1969. Thermus aquaticus gen.n.and sp.n., a nonsporulating extreme thermophile. J Bacteriol, 98(1): 289-297

Brock TD, 1995. The road to Yellowstone and beyond. Ann Rev Microbiol, 49: 1-28, doi: 10.1146/ annurev.mi.49.100195.000245 years at Madison, during that period as many as $34 \mathrm{Ph} . \mathrm{D}$ scholars and 18 post-doctoral fellows completed their research work under his mentorship (Brock, 1995). This great Yellow stone journey ended without earning money in his account was selfless scientific dedication that deserves felicitation. For his generous attribute this manuscript is our tribute.

Brock TD, 1997. The value of basic research: discovery of Thermus aquaticus and other extreme thermophiles. Genetics, 146(4): 1207-1210

Gelfand DH, Stoffel S, Lawer FC and Saiki RK, 1989. Thermostable Enzyme, United States patent number 4, 889,818, December 26, 1989 